\title{
Integrated coastal zone management in Italy: a gap between science and policy
}

\author{
Nicola Cantasano ${ }^{1}$ Gaetano Pellicone $^{1} \cdot{\text { Fabio } \text { Ietto }^{2}}^{2}$
}

Received: 3 March 2016 /Revised: 29 November 2016 / Accepted: 1 December 2016 /Published online: 24 April 2017

(C) Springer Science+Business Media Dordrecht 2016

\begin{abstract}
This paper introduces the need, in Italian countries, of a real integration of scientific knowledge into coastal policy. Actually, in Italy, still exists a gap between Science and Policy, interfering the implementation of an Integrated Coastal Zone Management (ICZM) process, while there is no coordination between local, regional and national authorities. This lack of an overall strategy has induced some regions to adopt regional plans for the sustainable development of their coastal areas, to compensate the shortcomings of a national planning. Besides, along Italian coasts, there is a heavy landscape urbanization producing conditions of environmental decay and highlighting the risk of erosions in littoral areas. In this critical context, it is necessary to adopt an effective Integrated Coastal Zone Management policy, to connect ecosystem and environmental approaches with the social and economic development of coastal areas. So, in Italian landscape, it is necessary to integrate the national cultural heritage into coastal
\end{abstract}

\section{Highlights}

-There is an Italian gap between Science and Policy.

- There is a rich cultural heritage in Italian coastal areas.

-In ICZM process, scientists and policy makers must work hand in hand.

Nicola Cantasano

cantasano@isafom.cs.cnr.it

Gaetano Pellicone

g.pellicone@isafom.cnr.it

Fabio Ietto

iettofabio@hotmail.com

1 National Research Council, Rende Research Unit, Institute for Agricultural and Forest Systems in the Mediterranean, Via Cavour 4/6, 87036 Rende, CS, Italy

2 Department of Biology, Ecology and Earth Science, University of Calabria, Via P. Bucci, Cubo 15/B, 87036 Rende, CS, Italy management, joining scientific and cultural issues. In this framework, ICZM process could play an important role connecting scientists and policy makers towards an effective integration for the social and economic growth of local people.

Keywords ICZM $\cdot$ Science $\cdot$ Policy $\cdot$ Italy

\section{Introduction}

The integration between Science and Policy is one of the main purposes in the implementation of an Integrated Coastal Zone Management (hereafter ICZM) in the Mediterranean basin. This principle of a joint outlook of coastal systems is one of the guidelines to direct European Policy in the management of their coastlines, according to a multiple approach (European Commission 2006). The idea of an Integrated Coastal Zone Management got into scientific community in '70s with the Mediterranean Action Plan (MAP) signed by 21 European countries in Barcellona (IUCN 1975). Afterwards, this new concept started to enter into Policy during the Earth Summit of Rio de Janeiro in 1992. In the following years, this kind of holistic approach to coastal system became the key issue for a sustainable development of coastal areas (Billè 2008). So, European Policy on Mediterranean Sea has been directed towards the protection of the ecological status of coastal systems (Ricketts and Harrison 2007; Barnes and McFadden 2008; Borja et al. 2010). In this framework the Protocol on ICZM, signed by Mediterranean countries in 2008, is the first legal instrument on this subject (Barale and Özhan 2010). Actually, the implementation of ICZM program in the Mediterranean Basin is variable for the different scientific and political conditions of each Mediterranean region (Fig. 1), as stated by a study about the progress of ICZM process in EU Member 


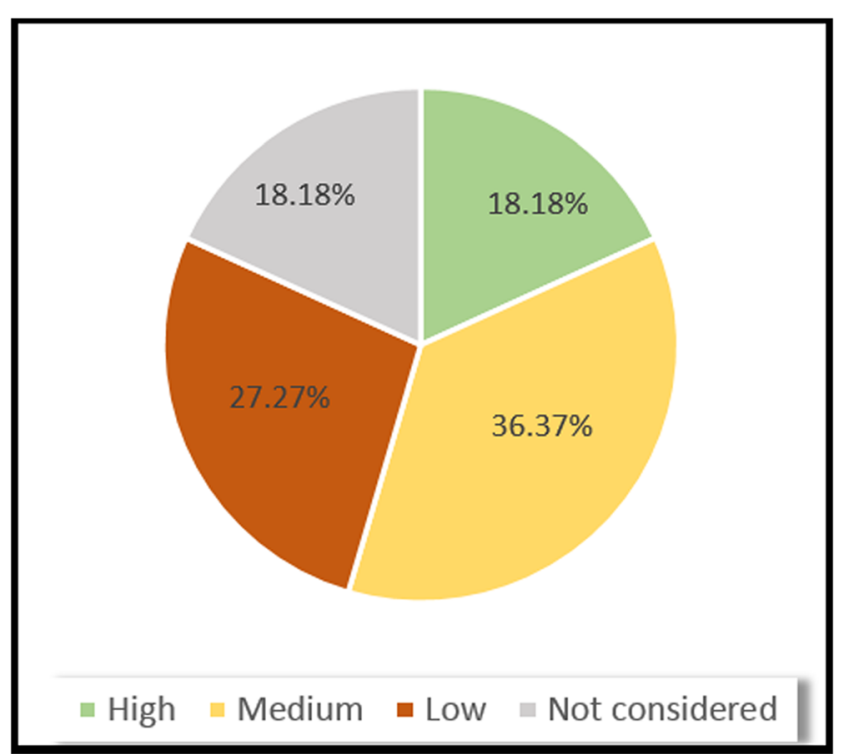

Fig. 1 Implementation of ICZM program in Mediterranean countries

states (European Commission 1999). On the base of the experiences conducted in European countries, it is possible to distinguish the following regional sharing:

- regions with a good experience in ICZM process where it has been realized a high level of its implementation;

- regions with a medium skill in the implementation of ICZM projects;

- regions with a low level in the realization of ICZM projects;

- regions where the legal and institutional arrangements prevent from developing ICZM projects.

Really, ICZM implementation in the Mediterranean countries has reached an impasse whereas efforts at research, planning and policy remain a series of fragmented actions without a connected cycle (Koutrakis et al. 2011).

In Italy, the peculiarity of coastal zone is until now misunderstood by Italian governments and the level of ICZM implementation is still very low.

This paper aims to present the actual condition of ICZM process in Italy with their first regional trials conducted by some advanced regions. It is, also, discussed about the main Italian gap between Science and Policy interfering the realization of ICZM program and the new challenges for its possible implementation in the future.

\section{The first regional trials}

In Italy, the lack of an overall strategy to carry out a national ICZM program for the sustainable development of coastal areas has carried some regions to adopt regional plans (Fig. 2), compensating the shortcomings of a national planning and the persistent State inertia (Rochette 2009). In this regard, have been proposed different regional approaches to coastal management on a local scale, proceeding from northern to southern Italy (Table 1), as listed below:

\section{Friuli Venezia Giulia}

In this region, located in the northern corner of Adriatic Sea, the Regional Agency for Environmental Protection (ARPA), in the context of SHAPE (Shape an Holistic Approach to Protect the Adriatic Environment) project, has carried out a pilot program for the monitoring of inland waters in Marano and Grado lagoons with specific instruments able to detect their biological and chemical parameters, so to reach a "good ecological status" of these waters until 2015.

\section{Veneto}

Also Veneto joins in SHAPE project with a pilot study developed to test and to create the management plane of an important Site of Communitary Interest named "IT3250003 Penisola del Cavallino: biotopi litoranei”, addressing special attention to the implementation of Natura 2000 areas, as cornerstones of ICZM plan along the coastline of Adriatic Sea. Besides, Consorzio Venezia Nuova is developing, in the Venice lagoon, the MOSE (Experimental Electromechanical Module) project. This system is constituted by a row of 78 mobile barriers able to temporarily isolate the historic Italian city of Venice and the contiguous areas to safeguard historical goods and natural ecosystems from high tides and, then, from flooding events.

\section{Liguria}

Liguria is one of the few Italian regions where it has been performed an ICZM plan enclosed in a Coastal Territorial Plan. This program is the main instruments to coordinate different efforts concerning the land-sea connections about harbor activities, collective use of sandy beaches and human settlements on the regional coastline. Besides, the region acts an important role in the Coastal Area Management Programme (CAMP-ITALY)) directed towards the implementation of ICZM program in some pilot areas of the Mediterranean basin.

\section{Emilia Romagna}

Emilia Romagna is the main leader in the realization, at regional level, of ICZM program not only for the launching of eighteen guidelines for its implementation but, also, for its active participation in some projects, as SHAPE and CAMP- 
Fig. 2 Regional approach of ICZM process in Italian regions

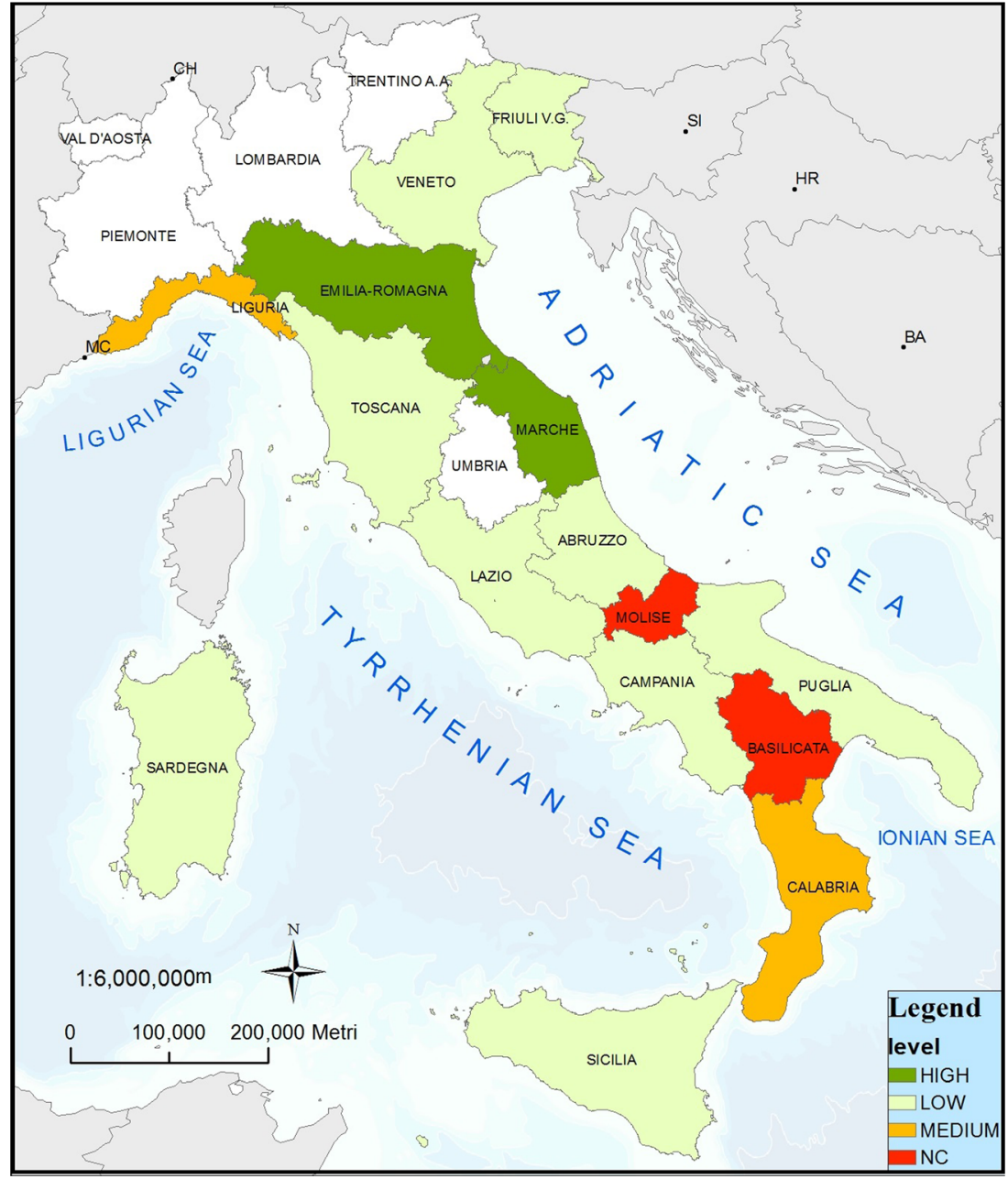

ITALY, to protect the Adriatic environment, at the border between coast and sea, following a holistic approach. In all these trials, the key points of both programs are:
- Defense of coastal system through compatible environmental interventions

- Geological settings
Table 1 Regional plans for Italian coasts

\begin{tabular}{|c|c|c|c|c|c|}
\hline Regions & $\begin{array}{l}\text { Coastal regional } \\
\text { plans }\end{array}$ & $\begin{array}{l}\text { Hydrogeological } \\
\text { plans }\end{array}$ & $\begin{array}{l}\text { Catchment } \\
\text { plans }\end{array}$ & $\begin{array}{l}\text { Experimental } \\
\text { plans }\end{array}$ & $\begin{array}{l}\text { ICZM } \\
\text { plans }\end{array}$ \\
\hline $\begin{array}{l}\text { Friuli Venezia } \\
\text { Giulia }\end{array}$ & & & & $\mathbf{x}$ & \\
\hline Veneto & & & & $\mathbf{x}$ & \\
\hline Liguria & & & & & $\mathbf{x}$ \\
\hline Emilia Romagna & & & & $\mathbf{x}$ & $\mathbf{x}$ \\
\hline Toscana & & $\mathbf{x}$ & $\mathbf{x}$ & & \\
\hline Abruzzo & $\mathbf{x}$ & & & $\mathbf{x}$ & \\
\hline Marche & & & & $\mathbf{x}$ & $\mathbf{x}$ \\
\hline Lazio & & & & $\mathbf{x}$ & \\
\hline Campania & & $\mathbf{x}$ & & & \\
\hline Calabria & $\mathbf{x}$ & $\mathbf{x}$ & $\mathbf{x}$ & & \\
\hline Puglia & $\mathbf{x}$ & & & $\mathbf{x}$ & \\
\hline Sardegna & $\mathbf{x}$ & & & $\mathbf{x}$ & \\
\hline Sicilia & & $\mathbf{x}$ & & & \\
\hline
\end{tabular}


- Development policy of inland regions

- Monitoring nets of flowing basins, transitional environments and coastal waters

- Quality control of pollutants loading to coastal system

- Depuration and management of second-hand waters

- Control in maritime transports

- Protection of coastal habitats and defense of marine biodiversity through the establishment of Marine Protected Areas (MPA)

- Sustainable tourism

- Agricultural policy

- Energy policy

- Fishery and Aquaculture

- Harbor activities

- Climatic changes and arising hazard conditions

- Mobility

\section{Toscana}

Toscana has approved and realized its Hydrogeological and River Basin planes for the planning and the management of coastal works to fight against erosional processes and to protect some built-up areas through soft operations, as sand replenishment and/or submerged breakwaters, leading to a beach accretion of its littoral fringe. The region is, also, involved in CAMP-ITALY project directed towards the implementation of ICZM in some pilot areas of the Mediterranean basin.

\begin{abstract}
Abruzzo
In this region, are operating a regional plan for an integrated management of its coastal area and, also, a SHAPE project for a holistic approach of the Adriatic environment. These programs are directed towards the attainment of an ICZM program characterizing the areas more vulnerable and strengthening coastal defense projects in some littoral areas more exposed to erosional processes.
\end{abstract}

\section{Marche}

Marche is one of the Italian regions where it has been approved an integrated plane for the management of its coastal area. This regional program aims to solve the main problem of a coastline exposed to an increasing withdrawal of its coastline due to erosional processes. The measures adopted in the plane are directed towards soft interventions in order to obtain the accretions of some sandy beaches through sand replenishment and/or submerged breakwaters. The region is, also, involved in an interregional and European project, named SHAPE, cofunded by European Union, suggesting a holistic approach to the Adriatic environment.

\section{Lazio}

Lazio is the national leader of a CAMP-ITALY project directed towards the implementation of ICZM process in some pilot area of the Mediterranean basin. In this direction, it has been established a Regional Commission on ICZM to set a working program and to manage an effective involvement of all the stakeholders involved in the project. CAMP-ITALY, supported by the National Institute on Environmental Protection (ISPRA), aims to realize a national strategy for a coastal integrated management, summarizing the different experiences of some Italian coastal regions so to exceed the fragmentation between institutional levels and planning items (ISPRA 2015).

\section{Campania}

In this region, is effective an operating plane, managed by The River Basin Authority of Campania, against the risk of erosion along the regional coastline. The main purpose of the project is to locate the coastal areas more exposed to erosional processes and to schedule possible solutions to mitigate and/or to remove risk conditions.

\section{Puglia}

In Puglia, has been adopted a regional plane for the protection and the collective use of its coastal areas, which are involved, also, in an interregional and European project, named SHAPE, for an holistic approach of the Adriatic environment. In both programs, this kind of vision aims, not only, to distinguish different levels of vulnerability of the regional coastline but, also, to detect the changing grade of environmental sensitivity in its coastal area.

\section{Calabria}

Calabria has adopted a plane for its hydrogeological assessment (PAI) and a River Basin program from which the Regional Plan of Coastal Management is, actually, in progress. This master plan is directed towards the protection of Calabrian coastal zone against the risk of erosion, characterizing 21 littoral areas that are particularly affected by erosional processes. However, each intervention of protection in the regional coastal area is managed by local municipalities and not by regional Authority. It follows that there is no coordination between the various municipal operations and, very often, these measures are at odds one each other, causing further damages to coastal system. 


\section{Sardegna}

Sardegna has adopted a regional plan where its coastal region is protected as a landscape good. This region is, also, involved in the CAMP-ITALY project directed towards the implementation of ICZM program in some pilot areas of the Mediterranean basin.

\section{Sicilia}

In Sicilia is effective a hydrogeological assessment plane (PAI) concerning the regional coastline more exposed to erosional process.

From these data, it appears, in all its evidence, the total absence of a national plan in coastal management and the short cooperation at regional levels between local authorities. So, it is hoped for the following points:

- A coordinate committee for the application of ICZM along regional coastlines.

- The implementation of a sharing approach in coastal development to shift powers and accountability from national to regional authorities, avoiding private management by each municipal authorities.

This kind of strategy could compel Italian state to an effective protection of coastal areas through the implementation of an ICZM national planning in a political process that could be realized in bottom-up trend (Cantasano and Pellicone 2014).

\section{State of the beaches in Italy}

Coastal areas have been always an important pole of development for mankind producing a high and, sometimes, an extreme urbanization beyond the limits of "carrying capacities" of the environmental system (Stankey 1984, Pearce and Kirk 1986, Romeril 1990, Canestrelli and Costa 1991, Moriani 1991, Butler 1996). These conditions have produced some losses in natural ecosystems with heavy consequences on environmental quality and on local economy (Girard 1993; Geoghegan 2002; Bengochea-Morancho 2003; Jim and Chen 2006; Ietto et al. 2014). As regards Italian coastal zone, $30 \%$ of national population, as 16.9 million of inhabitants, lives in littoral regions, concentrated in an area restricted to $13 \%$ of national territory (ISPRA 2013). An analysis in detail highlights that, along Italian coasts (within $300 \mathrm{~m}$ from coastline), have been urbanized $2.056 \mathrm{~km}^{2}$, as the $34 \%$ of the national coastal boundary. In Table 1, Table 2, are reported the values of urbanized surfaces at regional level, while in Fig. 3 are quoted the percentages at provincial level. In many urban agglomerations, the overcrowding and the consequent landscape urbanization along coastal areas have been occurred
Table 2 Urbanized surfaces, at regional level, within $300 \mathrm{~m}$ from coastline (ISPRA 2013)

\begin{tabular}{lll}
\hline Regions & $\begin{array}{l}\text { Surfaced urbanized } \\
\text { within } 300 \mathrm{~m} \text { from } \\
\text { coastline }\left(\mathrm{km}^{2}\right)\end{array}$ & $\begin{array}{l}\text { Percentages of } \\
\text { urbanization } \\
\text { within } 300 \mathrm{~m} \text { from } \\
\text { coastline }(\%)\end{array}$ \\
\hline Veneto & 154.5 & 23 \\
Friuli Venezia Giulia & 77.6 & 18 \\
Liguria & 88,7 & 66 \\
Emilia Romagna & 39.5 & 55 \\
Toscana & 150.0 & 26 \\
Marche & 49.0 & 59 \\
Lazio & 92.5 & 47 \\
Abruzzo & 36.4 & 62 \\
Molise & 10.5 & 25 \\
Campania & 116.9 & 48 \\
Puglia & 222.1 & 36 \\
Basilicata & 16.4 & 13 \\
Calabria & 201.1 & 47 \\
Sicilia & 372.2 & 37 \\
Sardegna & 428.1 & 14 \\
ITALIA & 2055.6 & 34 \\
\hline
\end{tabular}

without any appropriate town-planning scheme. This kind of urban approach has produced conditions of environmental deterioration in marine and coastal ecosystems and has affected the geo-morphological unstable equilibrium, highlighting the risk of erosion on sandy beaches (Ietto et al. 2014). Really, in the time lag 1950-2000, about the $30 \%$ of national coastline has suffered withdrawals wider than $25 \mathrm{~m}$. In particular, for sandy beaches ( $58 \%$ of national coastline), spreading out along $4.863 \mathrm{Km}$ in overall length, the $46 \%$ has suffered large changes producing a total negative sedimentary budget (Fig. 4) with an overall soil loss of $54 \mathrm{~km}^{2}$ (ISPRA 2013). So, this condition highlights a widespread and marked erosional trend of sandy beaches, at a national level, that in this last decade appears in an exponential and fast growth (Pranzini and Rossi, 2014). Amongst this national appraisal, the coastal regions more damaged, owing to larger withdrawals, are Calabrian and Adriatic coasts. The coastal area is a dynamic landscape and its changes occur, particularly, in sandy beaches with fast variations in the coastal outline and, therefore, with beach surfaces rising out and/or submerged in continuous evolution. The main reasons of coastal erosion are, not only, related to natural phenomena as the rising of sealevel and/or the erosional action by hydrodynamic forces, but also, to human activities that attend on coastal equilibrium sometimes changing its unstable geo-morphological equilibrium. In particular, Calabrian coasts and some littoral areas along the Adriatic Sea have different and distinctive morphological characteristics that expose their coastal regions to a 


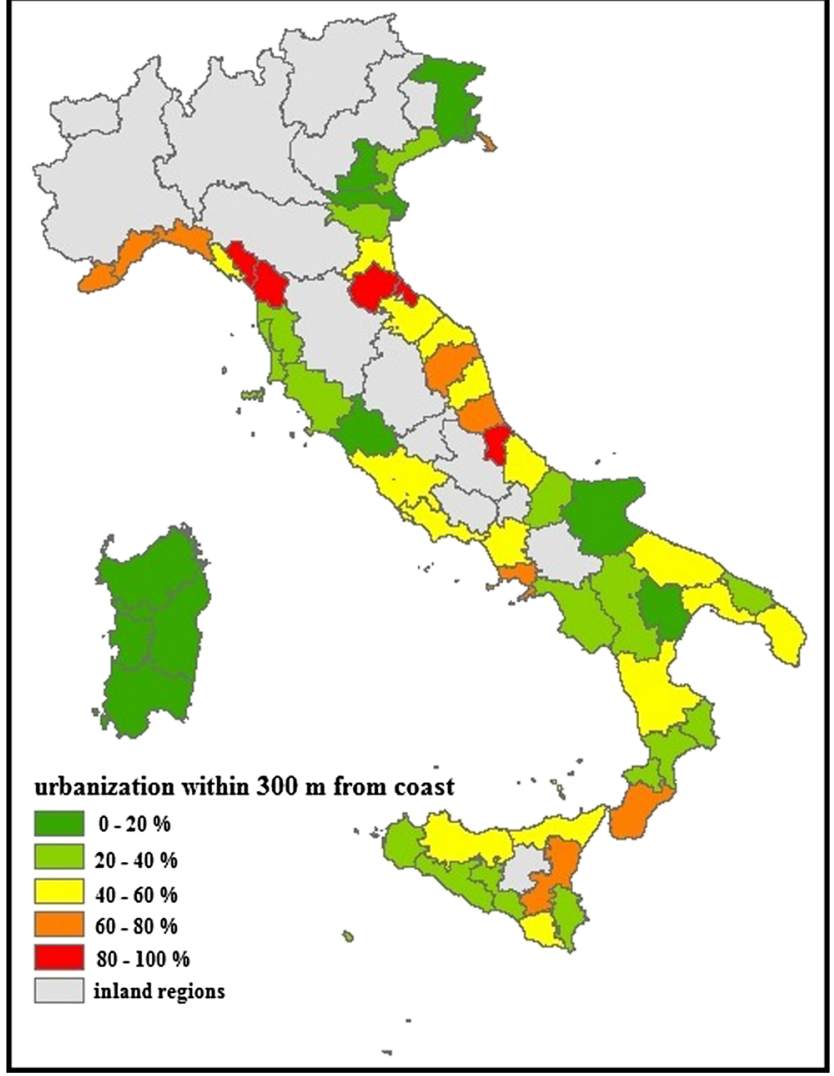

Fig. 3 Urbanization, at provincial level, within $300 \mathrm{~m}$ from coastline (ISPRA 2013)

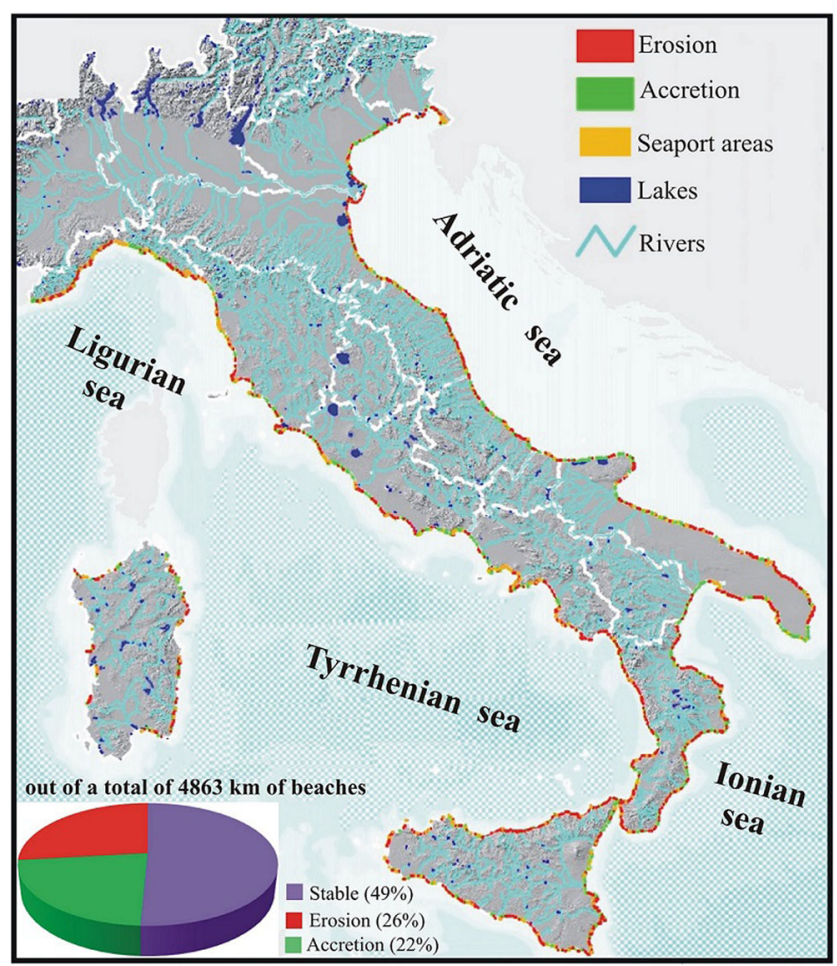

Fig. 4 Italian coastline erosion in the time lag 1950-2000, with only data erosion wider than $25 \mathrm{~m}$ (ISPRA 2013, modified) high erosional risk. Besides, the urban development in seaboard zone, often occurred without any appropriate town planning, produces a confused overbuilding in coastal landscape with heavy consequences in human wellbeing (Ietto et al. 2014). In this way, actions as:

- urbanization within $300 \mathrm{~m}$ from coastline and destruction of dune areas;

- buildings in riverside area and/or within fluvial beds, which have been buried in undersized water piping;

- implementation of road and railway networks, running parallel and close to coastline with several bottlenecks along the river pathways;

- hydraulic works as artificial riverbanks, bridles and cementation of waterways;

- sediment extractions from riverbeds;

have produced, year by year, a gradual reduction, until an almost total loss of river solid transport to sea with a consequent poor nourishment of coastal system. As a direct consequence, it has been occurred the progressive deterioration of the coastal morphological equilibrium and, accordingly, an increase of erosion in sandy beaches as well as flood hazards (Ietto et al. 2014). In this critical context, it is evident that a holistic approach, such as ICZM policy, could be able to connect the right management of natural processes with the social and economic development in littoral areas (Kelleher and Kenchington 1990). Really, ICZM process could produce not only, positive outcomes for an effective coastal defense against the risk of erosion but, also, the sustainable development of coastal areas on middle and long terms.

\section{The Italian gap}

The Italian coastal planning is, actually, characterized by an extreme fragmentation between public, regional and local authorities. Besides, the lack of national regulations is, partially, offset by the presence of many regional laws that establish programs for an integrated management of coastal areas (ISPRA 2015). In Italy, different plans for the management of Italian coasts have been realized in thirteen Italian regions, based on local/regional initiatives. However, the effectiveness of these actions are subjected to "the tyranny of small and local decisions" (Odum 1982) and not to a global program as stated by ICZM principles. Today, still exists a gap between scientific community involved in ICZM process and policy makers for an effective implementation of ICZM in Italian coastal regions. Actually, we live in a strange impasse because the efforts at research, planning and policy in ICZM achievement remain disjointed without any temporal and territorial consistency. The main obstacles, already envisaged for other 
Mediterranean countries (Shipman and Stojanovic 2007), to an effective ICZM implementation in Italy, are:

1. The fragmentary nature of responsibilities: local, regional and national authorities suffer for the high degree of confusion about coastal management.

2. The national policy gap: the mess about responsibility is highlighted by the total absence of a national coordination in ICZM implementation. This critical state results in a policy vacuum at national level that leaves local and regional authorities without any guidance.

3. Information gaps and obstacles: the lack of any interaction between the different actors involved in ICZM implementation is a real problem that could be solved only by a close dialogue between scientific community and policy makers.

Really, Italy holds an important geographical position, in the center of Mediterranean area, with a long coastal boundary and a great importance in the European context but, even so, there is not, until now, a strategic national approach to ICZM. One of the main troubles for its implementation might be the high administrative decentralization of the country and the extreme fragmentation between different levels of coastal government.

Today, ICZM process is compelled in a shady zone between Science and Policy, restricted to local and temporary projects without any national coastal planning. To solve this failure, scientists, policy makers and all the stakeholders should appreciate the key role of ICZM in connecting words still divided by outdated limits, so to manage coastal areas as illustrated by the following pattern (Fig. 5).

By this way, ICZM could become a dynamic process where scientists and policy makers develop a common strategy to achieve the sustainable development of coastal regions, realizing an effective integration between economic sectors, scientific community, administrative field and institutional levels.

\section{An outlook for the future}

At the time, the management plans on the landward side of coastal regions aim to an unreasonable urban development, without any landscape planning, while the management of its sea-word side is extremely specific with no connection between terrestrial and marine environments. Really, coastal area is a wide and diverse zone connecting different landscapes (Bin et al. 2009), as are:

- inland regions influencing sea by rivers;

- coastal regions including wetlands, marshlands and other areas close to sea;

- coastal waters including estuarine and shallow seas;

- neritic waters inside the continental shelf.

As a framework to connect these marine and terrestrial landscapes, ICZM process has been suggested by UE to become the key issue for their development. Today, there are some problems about the lack of recognition of cultural heritage in ICZM plans (Goodhead and Aygen 2007). By this way, the Europa Nostra Bergen Declaration issued on 2005 (Europa Nostra 2005) has suggested European countries to include heritage management in the implementation of ICZM planning. The guidelines of this policy, drDDD awn by European forums (Solent Forum 1997) are:

- preserve historic and archeological sites from urban development;

- increase the protection of terrestrial and marine archeological sites;
Fig. 5 Ideal scheme of ICZM pattern

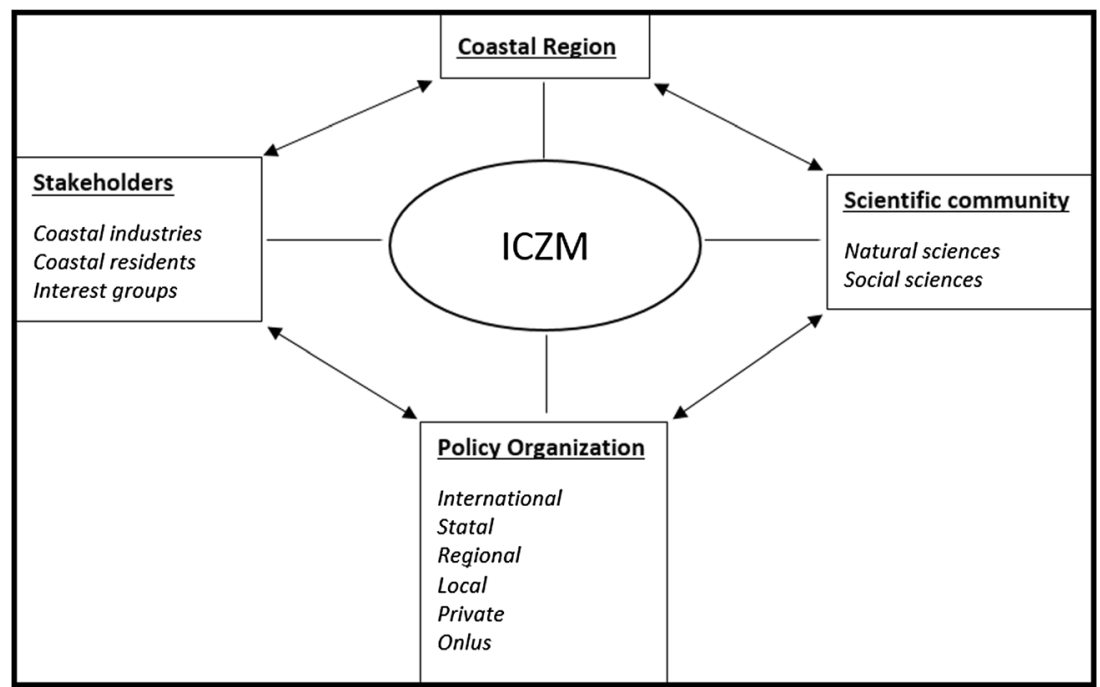


Fig. 6 Model of coastal system connected in ICZM process

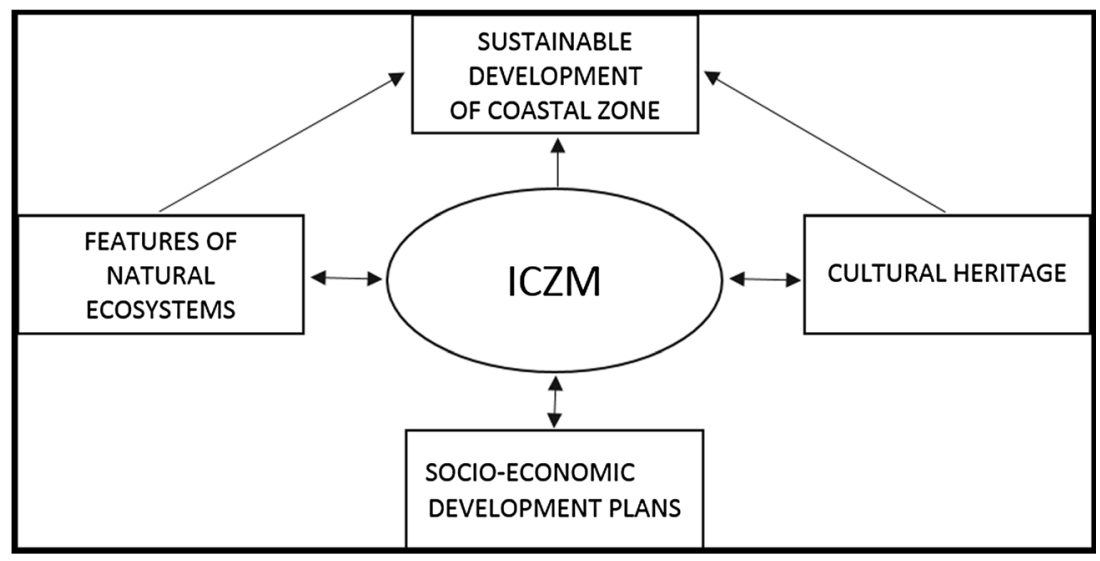

- recognize the importance of maritime archeology within coastal defence policies;

- promote a strategic plan for archeological conservation;

- improve the information base.

So, a correct landscape planning could be the ideal solution to include an effective management of cultural heritage into ICZM process for an integrated approach of coastal areas. This new kind of ICZM planning is, particularly, fitted in Italy, which holds a rich cultural heritage, mostly located in littoral regions (Vallega 2001). In Italian landscape, where interact many natural and human factors, is very important to protect the natural resources, within an ecosystem approach, but also to appreciate our cultural heritage located in seaboard as, for instance, the case of some coastal towers located along the Calabrian Tyrrhenian coastline of Cosenza Province in southern Italy (Cantasano 2013). Therefore, it is necessary to join in the same landscape unit the cultural heritage into the coastal plans integrating scientific, policy and administrative issues with suitable initiatives for the improvement of cultural heritage. By this way, it is established a new kind of landscape order based on the principle of "wide area" (Gambino 2004) where coastal areas become cultural expression, joining the intrinsic value of natural goods (Vallega 1993) with the presence of human being (Naveh and Lieberman 1994).

\section{Conclusions}

Mediterranean Sea covers only $0.8 \%$ of planet's water but, in spite this low percentage, it holds 1.351 vegetal species and 7.241 animal ones, as, respectively, $16.2 \%$ and $5.5 \%$ of the worldwide marine biota (Bianchi and Morri 2000). So, this basin is an important hot-spot for biodiversity and conservation issues. At the same time, Mediterranean coastal regions provide many important services for human well-being, as job opportunities in fishing and tourism, places for recreation, occasions for commercial activities and potential sink for
Carbon sequestration (Millenium Ecological Assessment 2005). However, Mediterranean Sea is exposed to some environmental and social risks as biodiversity loss, human overpopulation, coastal erosion and marine pollution with ecological and socio-economic consequences, having negative effects on ecosystem services and human societies in the littoral areas. In this critical state, Science could play an important role in addressing scientists, policy makers and coastal managers towards a real collaboration, strengthening an effective integration between scientific, managerial and political communities to enhance coastal resilience (Petes et al. 2014). In this framework, ICZM process, as holistic and dynamic approach to landscape planning, is the final goal to integrate Science and coastal management (Olsen et al. 1997; Smith 2002). Nevertheless, this kind of integration is very difficult for the actual lack between scientists and policy makers. In the Mediterranean region, ICZM national strategies have been developed for four countries (France, Malta, Slovenia and Spain) while in two nations these actions are ongoing (Cyprus and Greece). Only three countries have not submitted national programs (Croatia, Italy and Turkey) (Rupprecht Consult 2006). In Italy, this problem could be solved through the inclusion of the national cultural heritage in an effective ICZM process able to express scientific data into political actions. So, integration becomes the key-word to coordinate public and private efforts towards operating results in ICZM planning (Clark 1997). This blending of voices could be performed not only in horizontal direction, whereas public, private and governmental sectors are joined all together in the same pattern, but also, in vertical direction through the involvement of all levels from national to regional and local ones. By this way, coastal system could become and ideal model where ICZM holds a central position able to connect different sides of coastal system joining social, economic, ecological and cultural values in a global pattern (Fig. 6). According to this statement, ICZM plans could manage all the different points of view to realize a real and effective coordination in the different activities involved in coastal planning. In conclusion, the Italian coastal region could 
become a typical model where the natural features of coastal ecosystems, the planning of a human development towards long-term socio-economic outcomes and the protection of our rich cultural heritage interact for the social and economic growth of local people introducing a broader approach into ICZM process.

\section{References}

Barale V, Özhan E (2010) Advances in Integrated Coastal management for the Mediterranean \& Black Sea. J Coast Conserv 14:249-255

Barnes C, McFadden KW (2008) Marine ecosystem approaches to management: challenges and lessons in the United States. Mar Policy 32: 387-392

Bengochea-Morancho A (2003) A hedonic valuation of urban green spaces. Landscape Urban Planning 66:35-41

Bianchi CN, Morri C (2000) Marine biodiversity of the Mediterranean Sea: situation, problems and prospects for future research. Mar Pollut Bull 40(5):367-376

Billè R (2008) Integrated Coastal Zone Management: four entrenched illusions. SAPIENS 1(2):1-12

Bin C, Hao H, Weiwei Y, Senlin Z, Jinkeng W, Jinlong J (2009) Marine biodiversity conservation based on integrated coastal zone management (ICZM) - A case study in Quanzhou Bay, Fujian, China. Ocean Coast Manag 52:612-619

Borja A, Dauer DM, Elliott M, Simenstad C (2010) Medium and longterm recovery of estuarine and coastal ecosystems: patterns, rates and restoration effectiveness. Estuar Coasts 33:1249-1260

Butler RW (1996) The concept of carrying capacity for tourism destinations: dead or merely buried? Prog Tour Hosp Res 2(3-4):283-294

Canestrelli E, Costa P (1991) Tourism carrying capacity: a fuzzy approach. Ann Tour Res 18(2):295-311

Cantasano N (2013) Le torri costiere, sentinelle dell'ambiente nel Tirreno cosentino. Territori 17:38-43

Cantasano N, Pellicone G (2014) Marine and river environments: a pattern of Integrated Coastal Zone Management (ICZM) in Calabria (Southern Italy). Ocean Coast Manag 89:71-78

Clark JR (1997) Coastal zone management for the new century. Ocean Coast Manag 37(2):191-216

Europa Nostra (2005) Coastline press release, The Hague: European Commission. (Online) URL: http://europanostra.org/declaration coastalculture.htm. Accessed 14 June 2005

European Commission (1999) Towards a European Integrated Coastal Zone Management (ICZM) strategy: general principles and policy options. Office for Official Publications of the European Communities, Luxembourg, pp. 1-35

European Commission (2006) Green Paper: towards a future maritime policy for the union: a European Vision for the Oceans and Seas. Bruxelles. (Online) URL: http://ec.europa. eu/maritimeafairs/pdf/greenpaper_brochure_en.pdf

Gambino R (2004) Conservazione e pianificazione dei sistemi di area vasta. In: W.W.F. Italia Onlus (ed) Ecoregioni e reti ecologiche, la pianificazione incontra la conservazione. Edicomprint, Roma, pp 34-36

Geoghegan J (2002) The value of open spaces in residential land use. Land Use Policy 19:91-98

Girard LF (1993) Estimo, economia ambientale e sviluppo sostenibile. In: Angeli F (ed) Estimo ed economia ambientale, le nuove frontiere nel campo della valutazione. Studi in onore di Carlo Forte, Milano, pp $13-43$

Goodhead T, Aygen Z (2007) Heritage management plans and integrated coastal management. Mar Policy 31:607-610
Ietto F, Salvo F, Cantasano N (2014) The quality of life conditioning with reference to the local environmental management: a pattern in Bivona country (Calabria, Southern Italy). Ocean Coast Manag 102:340-349

Istituto Superiore per la Protezione e la Ricerca Ambientale (ISPRA) (2013) Annuario dei dati ambientali. Biblioteca Nazionale Centrale, Roma, pp. 137-148

Istituto Superiore per la Protezione e la Ricerca Ambientale (ISPRA) (2015) Pianificazione integrata della fascia marino-costiera. Reticula 10:1-2

IUCN (1975) International conference on marine parks and reserves: recommendations. Special Supplement to the IUCN Bull 6 (7)

Jim CY, Chen WY (2006) Impacts of urban environmental elements on residential housing prices in Guangzhou (China). Landscape. Urban Planning 78:422-434

Kelleher G, Kenchington R (1990) Guidelines for the establishment of marine protected areas. World Conservation Union, Gland

Koutrakis E, Sapounidis A, Marzetti S, Marin V, Roussel S, Martino S, Fabiano M, Paoli C, Rey-Valette H, Povh D, Malvárez CG (2011) ICZM and coastal defence perception by beach users: lessons from the Mediterranean coastal area. Ocean Coast Manag 54:821-830

Millenium Ecological Assessment (2005) Ecosystem and human wellbeing: synthesis. Island Press, Washington

Moriani G (1991) Manuale di ecocompatibilità. Marsilio, Venezia

Naveh Z, Lieberman AS (1994) Landscape ecology. Theory and Applications, 2nd edn. Springer, New York

Odum E (1982) Environmental Degradation and the Tyranny of Small Decisions. Bioscience 32(9):728-729

Olsen SB, Tobey J, Kerr M (1997) A common framework for learning from ICM experience. Ocean Coast Manag 37:155-174

Pearce DG, Kirk RM (1986) Carrying capacities for coastal tourism. UNEP Industry and Environment 9(1):3-7

Petes LE, Howard JF, Helmuth BS, Fly EK (2014) Science integration into US climate and ocean policy. Nat Clim Chang 4:671-677

Pranzini E, Rossi L (2014) Protocollo per il monitoraggio dell'evoluzione costiera. In: Cipriani F (ed) Monitoraggio dell'erosione costiera - una rete di osservatori regionali, Progetto ResMar. Firenze, pp 8-56

Ricketts PJ, Harrison P (2007) Coastal and Ocean management in Canada: moving into the twenty-first Century. J Coast Zone Manag 35(1):5-22

Rochette J (2009) Challenge, dialogue, action... Recent developments in the protection of coastal zones in Italy. J Coast Conserv 13:131-139

Romeril M (1990) Tourism planning and the concept of carrying capacity. UNEP, Paris, pp. 1-208

Rupprecht Consult, Forschung \& Beratung Gmbh, International Ocean Institute (2006) Evaluation of Integrated Coastal Zone Management (ICZM) in Europe. Cologne [online] Available: http://www3. rupprecht-consult.eu/uploads/tx_rupprecht/. Accessed 01/03/2016

Shipman B, Stojanovic T (2007) Facts, Fictions, and Failures of Integrated Coastal Zone Management in Europe. Coast Manag 35: $375-398$

Smith HD (2002) The role of the social sciences in capacity building in ocean and coastal management. Ocean Coast Manag 45(9-10):573-582

Solent Forum (1997) Strategic guidance for the Solent. In: Solent Forum, Winchester, pp 20-26

Stankey GH (1984) Carrying capacity in recreational settings: evolution, appraisal, and application. Leis Sci 6(4):453-473

Vallega A (1993) A conceptual Approach to Integrated Coastal management. Ocean Coast Manag 21:149-162

Vallega A (2001) Focus on integrated coastal management - comparing perspectives. Ocean Coast Manag 44:119-134 